\title{
SERODIAGNOSIS OF HUMAN BOCAVIRUS 1 INFECTION AMONG HOSPITALISED CHILDREN WITH LOWER RESPIRATORY TRACT INFECTION IN LATVIA
}

\author{
Inga Ziemele ${ }^{1,2, \#}$, Man $\mathrm{Xu}^{3}$, Anda Vilmane ${ }^{4}$, Santa Rasa-Dzelzkalēja ${ }^{4}$, \\ Klaus Hedman ${ }^{3,5}$, Maria Söderlund-Venermo ${ }^{3}$, Dace Gardovska ${ }^{1,2}$, \\ Zaiga Nora-Krūkle ${ }^{4}$, and Modra Murovska ${ }^{4}$ \\ ${ }^{1}$ Children's Clinical University Hospital, 45 Vienības Av., Rīga, LV-1004, LATVIA \\ 2 Department of Pediatrics, Rīga Stradiṇš University, 16 Dzirciema Str., Rīga, LV-1007, LATVIA \\ ${ }^{3}$ Department of Virology, University of Helsinki, Haartmaninkatu 3 PO BOX 21, Helsinki, FI-00014, FINLAND \\ ${ }^{4}$ Institute of Microbiology and Virology, Rīga Stradiṇš University, 5 Rātsupītes Str., Rīga, LV-1067, LATVIA \\ ${ }^{5}$ Helsinki University Hospital Laboratory Service, Stenbäckinkatu 9 PO BOX 100, Helsinki, FI-00029, FINLAND \\ \# Corresponding author, inga.ziemele@ rsu.lv
}

Contributed by Modra Murovska

\begin{abstract}
Since its discovery in 2005, human bocavirus 1 (HBoV1) has globally been one of the most common respiratory viruses. It is currently accepted that HBoV1 is a pathogen, causing upper and lower respiratory tract infections (LRTIs) in children. However, due to the prolonged HBoV1 DNA shedding from the upper airways and the subsequent high rate of co-detections with other respiratory viruses, the interpretation of positive polymerase chain reaction results is challenging. The aim of this study was to identify acute HBoV1 infections by the presence of HBoV1-specific IgM and IgG measured by competition enzyme immunoassay, to elucidate the induction of Th1/Th2 cytokines, and to describe the clinical characteristics associated with acute HBoV1 infection in hospitalised children less than five years of age with LRTI. HBoV1 IgM was detected in 19/102 (18.6\%) and IgG in 66/102 (64.7\%) patients. HBoV1 IgM was most frequently found in patients aged 13 to 24 months. Pneumonia and acute wheezing were the most common clinical diagnoses among HBoV1 IgM positive patients. The seroprevalence of HBoV1-specific IgG increased with age, reaching $85 \%$ by the age of five years. INF- $\gamma$, IL-4, IL-5, and IL-10 were observed to be higher in patients with acute HBoV1 infection.
\end{abstract}

Key words: human bocavirus, lower respiratory tract infection, serology, cytokines, children.

\section{INTRODUCTION}

Human bocavirus 1 (HBoV1) belongs to the Parvoviridae family, Parvovirinae subfamily and Bocaparvovirus genus and is classified as the second human-pathogenic parvovirus. Since its discovery in 2005, it has been found globally throughout the year (Allander et al., 2005; Qui et al., 2017). Studies have shown that HBoV1 causes lower respiratory tract infections (LRTIs) like bronchiolitis, acute wheezing and pneumonia, mainly in young children, aged six months to five years (Kesebir et al., 2006; Allander et al., 2007; Fry et al., 2007; Söderlund-Venermo et al., 2009; Christensen et al., 2010; Don et al., 2010; Qui et al., 2017; Nascimento-
Carvalho et al., 2018). Although the exact clinical picture of an acute HBoV1 infection remains unclear, the most frequently described clinical symptoms of HBoV1-associated infection include fever, cough, rhinitis and wheezing (Jartti et al., 2012; Qui et al., 2017). Several clinical case reports have shown acute HBoV1 infection in life-threatening respiratory tract infections (Körner et al., 2011; Ursic et al., 2011; Edner et al., 2012; Ursic et al., 2015; Eskola et al., 2017).

In clinical studies, the most common method used to diagnose $\mathrm{HBoV} 1$ infection has been polymerase chain reaction (PCR), by which the prevalence of HBoV1 DNA in airway 
samples has been shown to range from 2 to $20 \%$ of hospitalised children with upper and lower respiratory tract infections (RTIs). However, due to the prolonged HBoV1 DNA shedding from the upper airways and the subsequent high rate of co-detections with other respiratory viruses, the interpretation of $\mathrm{HBoV} 1$-positive PCR results in acute RTI is problematic (von Linstow et al., 2008; Söderlund-Venermo et al., 2009; Martin et al., 2010; 2015).

In 2008, serological studies disclosed that RTIs due to $\mathrm{HBoV1}$ are systemic and elicit B-cell immune responses (Kantola et al., 2008). Since then, studies have shown that measurement of HBoV1-specific immunoglobulin (Ig) M and $\mathrm{IgG}$ can be used for diagnostic purposes to reveal acute HBoV1 infections (Kantola et al., 2008; SöderlundVenermo et al., 2009; Don et al., 2010; Karalar et al., 2010; Kantola et al., 2011; Xu et al., 2017; Nascimento-Carvalho et al., 2018). Due to antibody cross reactivity between HBoV1 and three other HBoVs, competition enzyme immunoassay (EIA) should be used (Kantola et al., 2011; Guo et al., 2012; Kantola et al., 2015).

To explain the HBoV1 pathogenesis and clinical characteristics, some studies have addressed also for $\mathrm{HBoV}$-specific T-cell immune responses, demonstrating the production of circulating cytokines in $\mathrm{HBoV}$-positive subjects and suggesting that $\mathrm{HBoV}$ infection can induce production of $\mathrm{T}$ helper (Th)-1 (Th1) and Th2 cytokines (Chung et al., 2008; Kumar et al., 2011; Hirose et al., 2015; Guido et al., 2016).

The aim of this study was to identify the presence of HBoV1-specific IgM and IgG by competition EIA, to elucidate the induction of Th1/Th2 cytokines, and to describe the clinical characteristics associated with acute HBoV1 infection in hospitalised children less than five years of age with LRTI in Latvia.

\section{MATERIALS AND METHODS}

Patients and sample collection. The study protocol was approved by the Ethics Committee of the Rịga Stradiňš University on 30 May 2013 and written informed consent was obtained from the parents/guardians of all the participating children.

In this cross-sectional study 102 children aged 28 days to 60 months and treated as inpatients for presumptive LRTI at the Department of Pediatrics, Children's Clinical University Hospital of Rīga, Latvia, were included and investigated from October 2013 to December 2016. Children presenting with symptoms of acute illness for more than ten days and those with severe chronic underlying illnesses were excluded.

On admission, a single blood sample was collected from each enrolled patient, and plasma was separated and kept at $-80{ }^{\circ} \mathrm{C}$ until testing.

Clinical definitions. On inspection, fever was defined as axillary temperature $>37.5^{\circ} \mathrm{C}$ (El-Radhi and Barry, 2006).
LRTI was defined according to the clinical definition criteria and/or chest roentgenogram with positive results (infiltrates). Chest X-rays were requested by a physician and analysed by a paediatric radiologist.

The clinical definition of LRTI was the following - one or more lower respiratory tract sign(s): rapidity or difficulty in breathing, chest wall in-drawing, and or abnormal auscultatory findings (crackles/crepitation or bronchial sounds) (Roth et al., 2008).

Fast breathing (tachypnea) was defined as a respiratory rate of $>60$ breaths/minute in children aged $<2$ months, $>50$ breaths/minute in children aged 2-12 months, and $>40$ breaths/minute in children aged 12-60 months (Anonymous, 1995).

HBoV1 serology. All 102 plasma samples were tested for HBoV1-specific IgM and $\mathrm{IgG}$ antibodies. Biotinylated virus-like particles (VLPs) of the recombinant major capsid protein VP3 were used as antigen in both the IgM and IgG EIAs (Söderlund-Venermo et al., 2009; Kantola et al., 2011). For removal of possible cross-reacting heterotypic HBoV2 and HBoV3 IgGs, non-biotinylated VLPs were used in competition assays as described previously (Kantola et al., 2011; Kantola et al., 2015). The positivity cut-offs in competitive and non-competitive IgG EIAs were 0.095 $($ mean +4 standard deviations (SD)) and 0.151 (mean + 4SD), respectively, and in non-competitive IgM EIA, 0.131 $($ mean $+4 \mathrm{SD})$.

Cytokines. Cytokine [tumor necrosis factor alpha (TNF- $\alpha$ ), interferon gamma (IFN- $\gamma$ ), interleukin (IL)-2, IL-4, IL-5, IL-10, IL-13] levels in cell-free blood plasma samples were analysed by a Luminex 200 System (Luminex Corporation, Austin, USA) using a Magnetic Luminex Screening Assay kit (R\&D Systems, Inc., Minneapolis, USA) in accordance with the manufacturer's instructions. Results were analysed using xPONET Software.

Level of interferon beta (IFN- $\beta$ ) was analysed in cell-free blood plasma samples using a commercial sandwich type EIA kit (EIA Kit for Interferon Beta, Cloud-Clone Corp., Houston, USA) according to the manufacturer's guidelines. Optical density was measured by a microplate reader (Multiscan Ascent, Thermo Electron Corporation, Waltham, USA) at $450 \mathrm{~nm}$, using the programme Ascent Software and the results were calculated using the Microsoft Excel software.

Other laboratory studies. Blood samples to analyse haemoglobin $(\mathrm{Hgb})$ and the non-specific inflammatory markers, white blood cell counts (WBC) and serum C-reactive protein (CRP), were obtained on admission and analysed by routine methods.

Statistical analysis. The statistical analysis was performed using the Statistical Package for the Social Sciences (SPSS), version 22. To determine significant differences of the data, Pearson's chi-square and Fisher's exact tests were 
used. $P$ values $<0.05$ were considered statistically significant.

\section{RESULTS}

Characteristics of study population. On admission, of the studied 102 patients, bronchiolitis was diagnosed in 4 $(3.9 \%)$, acute wheezing in $64(62.7 \%)$. Pneumonia occurred in $60(58.8 \%)$ cases, among which pneumonia was a complication of acute illness in $24(40 \%)$. The patients were divided into three age groups according to the proposed integrated age groups for paediatric trials (ContopoulosIoannidis et al., 2012).

The baseline characteristics of the study population are presented in Table 1. Fever and cough were present in all of the enrolled patients in this study. A statistically significant association was found among the different age groups and the presence of wheezing $(p=0.024)$.
HBoV1 serology. Of the 102 patients, HBoV1-specific IgM was found in $19(18.6 \%)$ patients, $7 / 19(36.8 \%)$ were positive only for HBoV1 IgM, and 12/19 (63.1\%) patients had also HBoV1-specific IgG antibodies. None of the patients aged 28 days to 12 months $(n=25)$ was positive for HBoV1 IgM. The highest prevalence of HBoV1 IgM was found in patients aged 13 to 24 months (Table 2). The differences in the presence of HBoV1 IgM antibodies at various age groups were statistically significant $(p=0.005)$.

In total, $66(64.7 \%)$ patients were positive for HBoV1 IgG antibodies. The HBoV1 IgG seroprevalence increased constantly in relation to age (Table 2 ). The mean age \pm SD of those 66 patients positive for HBoV1 IgG was $26.8 \pm 13.8$ months (range 2 to 59 months). HBoV1 IgG antibodies were found in $12 / 25$ (48\%) patients aged 28 days to 12 months, among them, $4 / 12(33.3 \%)$ were younger than six months.

Table 1

BASELINE CHARACTERISTICS OF STUDY POPULATION AND COMPARISON BETWEEN THE DIFFERENT AGE GROUPS IN PATIENTS WITH ACUTE LOWER RESPIRATORY TRACT INFECTIONS

\begin{tabular}{|c|c|c|c|c|}
\hline & All cases & 28 days $-12 \mathrm{mo}$ & $13 \mathrm{mo}-24 \mathrm{mo}$ & $25 \mathrm{mo}-60 \mathrm{mo}$ \\
\hline Characteristics & $(\mathrm{n}=102) \mathrm{n}(\%)^{1}$ & $(\mathrm{n}=25) \mathrm{n}(\%)^{1}$ & $(\mathrm{n}=37) \mathrm{n}(\%)^{1}$ & $(\mathrm{n}=40) \mathrm{n}(\%)^{1}$ \\
\hline \multicolumn{5}{|c|}{ Demographics } \\
\hline Age in months (median $\pm \mathrm{SD})$ & $22.2 \pm 12.9$ & $9.0 \pm 3.2$ & $21.0 \pm 3.4$ & $32.5 \pm 10.1$ \\
\hline Male gender & $60(58.8)$ & $12(48.0)$ & $21(56.7)$ & $27(67.5)$ \\
\hline Days of acute illness ${ }^{2}($ median $\pm S D)$ & $4.0 \pm 1.8$ & $4.0 \pm 1.8$ & $4.0 \pm 1.8$ & $4.0 \pm 1.9$ \\
\hline Days of hospitalization (median \pm SD) & $4.0 \pm 5.1$ & $6.0 \pm 1.9$ & $4.0 \pm 7.7$ & $4.0 \pm 2.7$ \\
\hline \multicolumn{5}{|c|}{ Epidemiological factors } \\
\hline Lack of breastfeeding & $34(33.3)$ & $7(28.0)$ & $11(29.7)$ & $16(40.0)$ \\
\hline Incomplete immunization & $29(28.4)$ & $11(44.0)$ & $12(32.4)$ & $8(20.0)$ \\
\hline Passive smoking & $38(37.2)$ & $8(32.0)$ & $13(35.1)$ & $17(42.5)$ \\
\hline \multicolumn{5}{|c|}{ Clinical signs and symptoms } \\
\hline Rhinitis & $77(75.4)$ & $22(88.0)$ & $26(70.2)$ & $29(72.5)$ \\
\hline Pharyngitis & $47(46.1)$ & $11(44.0)$ & $20(54.0)$ & $16(40.0)$ \\
\hline Conjunctivitis & $8(7.8)$ & $3(12.0)$ & $2(5.4)$ & $3(7.5)$ \\
\hline Wheezing & $53(51.9)$ & $18(72.0)$ & $20(54.0)$ & $15(37.5)$ \\
\hline Chest wall in drawing & $69(67.6)$ & $18(72.0)$ & $26(70.2)$ & $25(62.5)$ \\
\hline Abnormal auscultator findings & $98(96)$ & $24(96.0)$ & $36(97.2)$ & $38(95.0)$ \\
\hline Tachypnea & $42(41.1)$ & $8(32.0)$ & $16(43.2)$ & $18(45.0)$ \\
\hline \multicolumn{5}{|c|}{ Diagnosis based on chest X-ray } \\
\hline Bronchitis & $35 / 97^{3}(36.0)$ & $10 / 22^{3}(54.5)$ & $11 / 35^{3}(31.4)$ & $14(35.0)$ \\
\hline Pneumonia & $47 / 97^{3}(48.4)$ & $7 / 22^{3}(31.8)$ & $18 / 35^{3}(51.4)$ & $22(55.0)$ \\
\hline \multicolumn{5}{|c|}{ Non-specific laboratory studies } \\
\hline $\mathrm{WBC}\left(\mathrm{x} 10^{3} / \mu \mathrm{L}\right)$ (mean; range) & $13.3(3.4-38.38)$ & $13.8(4.9-23.6)$ & $15.3(5.8-28.3)$ & $11.2(3.4-27.0)$ \\
\hline $\mathrm{Hgb}(\mathrm{g} / \mathrm{dL})$ (mean; range) & $11.2(6.5-14.2)$ & $10.8(9.3-12.5)$ & $11.1(8.7-12.8)^{4}$ & $11.6(6.5-14.2)$ \\
\hline CRP (mg/L) (mean; range) & $23.4(0.3-179.0)$ & $17.3(0.8-69.2)$ & $22.7(6.5-128.2)$ & $28.3(0.7-179.0)$ \\
\hline
\end{tabular}


FREQUENCY OF HBOV1-SPECIFIC IGM AND IGG ANTIBODIES IN PATIENTS WITH LOWER RESPIRATORY TRACT INFECTION PER AGE GROUP

\begin{tabular}{|c|c|c|c|c|}
\hline Antibodies & $\begin{array}{l}28 \text { days- } 12 \mathrm{mo} \\
(\mathrm{n}=25) \mathrm{n}(\%)^{1}\end{array}$ & $\begin{array}{c}13 \mathrm{mo}-24 \mathrm{mo} \\
(\mathrm{n}=37) \mathrm{n}(\%)^{1}\end{array}$ & $\begin{array}{c}25 \mathrm{mo}-60 \mathrm{mo} \\
(\mathrm{n}=40) \mathrm{n}(\%)^{1}\end{array}$ & $p$-value ${ }^{2}$ \\
\hline HBoV1 $\operatorname{IgM}^{3}$ & $0(0)$ & $5(13.5)$ & $2(5.0)$ & 0.022 \\
\hline HBoV1 IgM/HBoV1 $\operatorname{IgG}^{4}$ & $0(0)$ & $7(18.9)$ & $5(12.5)$ & 0.022 \\
\hline HBoV1 $\operatorname{IgG}^{5}$ & $12(48.0)$ & $13(35.1)$ & $29(72.5)$ & 0.022 \\
\hline Total HBoV1 IgM & $0(0)$ & $12(32.4)$ & 7 (17.5) & 0.005 \\
\hline Total HBoV1 IgG & $12(48.0)$ & $20(54.0)$ & $34(85.0)$ & 0.002 \\
\hline
\end{tabular}

HBoV1, human bocavirus 1

${ }^{1}$ Data expressed as absolute numbers and percentage.

${ }^{2}$ Pearson chi-square and Fisher's exact test calculated among patient age groups and the presence of HBoV1-specific IgM and/or IgG antibodies.

${ }^{3}$ Patients positive only for HBoV1 IgM antibodies.

${ }^{4}$ Patients positive for both, HBoV1 IgM and IgG antibodies.

${ }^{5}$ Patients positive for HBoV1 IgG antibodies only.

The study group with evidence of HBoV1 seropositivity was subdivided into three subgroups, according to the presence of HBoV1 IgM and/or IgG antibodies (Table 2). By comparing the presence of HBoV1 IgM and IgG among the various age groups, a statistically significant difference was found $(p=0.022)$

The baseline characteristics of HBoV1-seropositive patients in subgroups are illustrated in Table 3. No significant differences in clinical characteristics were found in patients within these subgroups (Table 3).

Among the $48(80.0 \%)$ pneumonia cases out of 60 HBoV1seropositive patients, a chest X-ray was made in 42 cases, of which pneumonia was confirmed in all patients who were positive only for HBoV1 IgM-class antibodies ( $\mathrm{n}=5$; $100 \%$ ) or for both - HBoV1 IgM- and IgG-specific antibodies $(\mathrm{n}=9 ; 100 \%)$. In patients with only HBoV1 IgGclass antibodies, pneumonia was confirmed by chest X-ray in 28 of $34(73.6 \%)$ cases.

Of the 102 patients, 29 (28.4\%) did not have HBoV1specific IgM or IgG antibodies, $14(48.2 \%)$ of them were males. The mean age \pm SD of those $29 \mathrm{HBoV} 1$-seronegative patients was $15.6 \pm 7.9$ months (median $=6.0$, range 2 to 35 months). A statistically significant difference was observed in the presence of wheezing among the HBoV1-negatives and positives in the three serogroups ( $\mathrm{p}=$ 0.048). In other signs or symptoms of LRTI, no significant differences were found.

Cytokines. Multiplex cytokine levels were measured in 60 of enrolled patients' plasma samples. To investigate whether acute HBoV1 infection can induce production of Th1/Th2 cytokines, the mean cytokine levels were compared between patients with and without serological evidence of acute HBoV1 infection (Table 4).

The mean level of INF- $\gamma$ was higher in patients with evidence of acute HBoV1 infection (mean \pm SD; $164.1 \pm$
$75.5)$, in 33 of 60 patients the level of INF- $\gamma$ was below the detection level. The other Th1 cytokines TNF- $\alpha$ and IL-2 were undetectable in many patients, including those with acute HBoV1 infection (Table 4). No statistically significant differences were found when mean plasma concentrations of Th1 cytokines were compared between patients with and without acute HBoV1 infection.

The representative Th2 cytokine IL- 4 was detected above the detection threshold in 12 of 60 enrolled patients. The concentration of IL-4 was above detection limits in three patients with acute HBoV1 infection and was higher compared with patients without acute HBoV1 infection. IL-5 was detected in all 60 patients and among them, was higher in patients with acute HBoV1 infection $(31.4 \pm 2.5)$. Also the plasma concentration of IL-10 was higher in patients with acute HBoV1 infection $(85.9 \pm 79.7)$ (Table 4). Th2 cytokine IL-13 was undetectable in all 60 patients. When mean plasma concentrations of different Th2 cytokines were compared between two study groups, no statistically significant differences were found.

The INF- $\beta$ levels were higher in patients without acute HBoV1 infection, compared to the patient with acute HBoV1 infection (Table 4).

\section{DISCUSSION}

The clinical role of HBoV1 has been actively investigated since discovery of the virus. Previous studies based on PCR results have shown HBoV1 DNA to be frequently present in respiratory samples of patients with upper or lower RTI (Bastien et al., 2006; Foulongne et al., 2006; Manning et al., 2006; Allander et al., 2007; Fry et al., 2007; Söderlund-Venermo et al., 2009; Christensen et al., 2010; Kalaral et al., 2010; Nascimento-Carvalho et al., 2018). Along with other researchers, we previously demonstrated that HBoV1 is widespread among hospitalised children in 
BASELINE CHARACTERISTICS OF PATIENTS WITH DETECTABLE HBOV1-SPECIFIC IGM AND IGG ANTIBODIES IN SUBGROUPS

\begin{tabular}{|c|c|c|c|c|}
\hline \multicolumn{5}{|c|}{ Patients' subgroups depending on the presence of HBoV1-specific IgM and IgG antibodies } \\
\hline & HBoV1 $\operatorname{IgM}^{1}$ & HBoV1 IgM/IgG ${ }^{2}$ & HBoV1 $\mathrm{IgG}^{3}$ & $p$-value ${ }^{5}$ \\
\hline Characteristics & $(\mathrm{n}=7) \mathrm{n}(\%)^{4}$ & $(\mathrm{n}=12) \mathrm{n}(\%)^{4}$ & $(\mathrm{n}=54) \mathrm{n}(\%)^{4}$ & \\
\hline \multicolumn{5}{|c|}{ Demographics } \\
\hline Age in months (median $\pm \mathrm{SD}$ ) & $17.0 \pm 5.7$ & $24.0 \pm 9.9$ & $25.5 \pm 14.5$ & 0.677 \\
\hline Male gender & $5(71.4)$ & $7(58.3)$ & $34(62.9)$ & 0.853 \\
\hline Days of hospitalization (median $\pm \mathrm{SD}$ ) & $6.0 \pm 2.5$ & $3.5 \pm 12.6$ & $3.0 \pm 2.8$ & 0.443 \\
\hline \multicolumn{5}{|c|}{ Epidemiological factors } \\
\hline Lack of breastfeeding & $4(57.1)$ & $6(50.0)$ & $18(33.3)$ & 0.315 \\
\hline Incomplete immunization & $3(42.8)$ & $3(25.0)$ & $11(20.3)$ & 0.189 \\
\hline Passive smoking & $3(42.8)$ & $3(25.0)$ & $23(42.5)$ & 0.523 \\
\hline \multicolumn{5}{|c|}{ Clinical signs and symptoms } \\
\hline Rhinitis & $3(42.8)$ & $8(66.6)$ & $41(75.9)$ & 0.148 \\
\hline Pharyngitis & $3(42.8)$ & $5(41.6)$ & $25(46.2)$ & 1.000 \\
\hline Conjunctivitis & $0(0)$ & $1(8.3)$ & $6(11.1)$ & 1.000 \\
\hline Wheezing & $4(57.1)$ & $6(50.0)$ & $22(40.7)$ & 0.629 \\
\hline Chest wall in drawing & $5(71.4)$ & $9(75.0)$ & $32(59.2)$ & 0.659 \\
\hline Abnormal auscultator findings & $7(100)$ & $12(100.0)$ & $50(92.5)$ & 1.000 \\
\hline Tachypnea & $3(42.8)$ & $5(41.6)$ & $18(33.3)$ & 0.777 \\
\hline \multicolumn{5}{|c|}{ Diagnosis on admission } \\
\hline Bronchiolitis & $0(0)$ & $0(0)$ & $1(1.8)$ & 1.000 \\
\hline Acute wheezing & $4(57.1)$ & $6(50.0)$ & $35(64.8)$ & 0.617 \\
\hline Pneumonia & $5(71.4)$ & $9(75.0)$ & $34(62.9)$ & 0.776 \\
\hline Hgb (g/dL) (mean; range) & $11.3(10.6-11.7)^{7}$ & $11.2(9.6-12.8)$ & $11.3(6.5-13.3)$ & - \\
\hline CRP (mg/L) (mean; range) & $23.7(0.8-83.0)$ & $26.7(2.03-124.4)$ & $24.7(0.3-179.0)$ & - \\
\hline \multicolumn{5}{|l|}{ HBoV1, human bocavirus 1} \\
\hline \multicolumn{5}{|c|}{${ }^{1}$ Patients positive only for HBoV1 IgM antibodies. } \\
\hline \multicolumn{5}{|c|}{2 Patients positive for both HBoV1 IgM and IgG antibodies. } \\
\hline \multicolumn{5}{|c|}{${ }^{3}$ Patients positive only for HBoV1 IgG antibodies. } \\
\hline \multicolumn{5}{|c|}{${ }^{4}$ Data expressed as absolute numbers and percentage if not otherwise specified. } \\
\hline \multicolumn{5}{|c|}{${ }^{5}$ Fisher's exact test calculated among patient subgroups and the baseline clinical characteristics. } \\
\hline \multicolumn{5}{|c|}{${ }^{6}$ Days of acute illness, when the patient was enrolled in the study. } \\
\hline${ }^{7}$ For one patient in this group, the res & 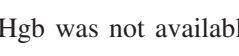 & & & \\
\hline
\end{tabular}

Latvia, as $32.0 \%$ of the 130 nasopharyngeal aspirates (NPAs) were shown to be HBoV1-DNA positive (NoraKrukle et al., 2015). However, others have shown HBoV1 DNA to be found also in asymptomatic children, and the virus moreover persists in the respiratory tract long after infection. Therefore, qualitative PCR is unreliable in diagnosis of acute HBoV1 infection (von Linstow et al., 2008; Blessing et al., 2009; Martin et al., 2010; Martin et al., 2015; Qui et al., 2017; Xu et al., 2017).

Thus far, several studies have provided evidence that occurrence of $\mathrm{HBoV} 1$-specific $\operatorname{IgM}$ and a 4-fold increase in
HBoV1-specific IgG antibodies is a more accurate indicator of acute HBoV1 infection (Kantola et al., 2008; SöderlundVenermo et al., 2009; Don et al., 2009; Kantola et al., 2011; Nascimento-Carvalho et al., 2012; Meriluoto et al., 2012; Nascimento-Carvalho et al., 2018). This is the first study where HBoV1 LRTI has been diagnosed by serology and where also cytokines have been measured.

In this cohort, $18.6 \%$ of all patients had HBoV1 IgM antibodies and of them $36.8 \%$ displayed only HBoV1 IgM, whereas $63.2 \%$ had combined positivity for HBoV1 IgM and $\mathrm{IgG}$ antibodies, pointing to acute or recent HBoV1 in- 
PROFILES OF PLASMA CYTOKINES IN PATIENTS WITH AND WITHOUT ACUTE HBOV1 INFECTION

\begin{tabular}{|c|c|c|c|}
\hline \multirow[t]{2}{*}{ Cytokines } & $\begin{array}{l}\text { Cases without acute } \\
\text { HBoV1 infection }\end{array}$ & $\begin{array}{l}\text { Cases with acute } \\
\text { HBoV1 infection }\end{array}$ & \multirow[t]{2}{*}{$p$-value ${ }^{3}$} \\
\hline & $\begin{array}{c}\mathrm{n}=48 \\
\text { mean } \mathrm{pg} / \mathrm{ml} \text { (number } \\
\text { of samples with } \\
\text { detectable level of } \\
\text { cytokine) }\end{array}$ & $\begin{array}{c}\mathrm{n}=12 \\
\text { mean } \mathrm{pg} / \mathrm{ml} \text { (number } \\
\text { of samples with } \\
\text { detectable level of } \\
\text { cytokine) }\end{array}$ & \\
\hline INF- $\gamma$ & $140.5(20)$ & $164.1(7)$ & 0.095 \\
\hline TNF- $\alpha$ & $16.1(4)$ & $\mathrm{NA}^{4}$ & - \\
\hline IL-2 & $50.8(8)$ & $\mathrm{NA}^{4}$ & - \\
\hline IL-4 & $27.9(9)$ & $29.5(3)$ & 0.467 \\
\hline IL-5 & $30.3(48)$ & $31.4(12)$ & 0.461 \\
\hline IL-10 & $70.8(14)$ & $85.9(4)$ & 0.265 \\
\hline INF- $\beta$ & $75.9(48)$ & $62.3(12)$ & 0.366 \\
\hline
\end{tabular}

\footnotetext{
${ }^{1}$ HBoV1-seronegative patients and those positive only for HBoV1-IgG.

${ }^{2}$ Patients positive for HBoV1-IgM.

${ }^{3}$ Likelihood Ratio calculated among cases with and without acute HBoV1 infection and mean level of plasma cytokines.

${ }^{4} \mathrm{NA}$, the cytokine concentration was under the detection level in all the patients in this group.
}

fection, respectively. The mean age of HBoV1 IgM positives was 23.3 months. By serology, it has been shown that HBoV1 primary infections occur in early childhood. In a previous study, $97 \%$ of children below the age of 3 years were observed to be seroconverted, however, cross-reactivity was not blocked, perhaps giving an overestimate of the true seroprevalence (Kantola et al., 2008). Another study conducted in Germany reported that acute $\mathrm{HBoV}$ infection is most frequent in children aged 10-30 months, and only $1.8 \%$ of children after 30 months of age showed markers of acute $\mathrm{HBoV}$ infection (Karalar et al., 2010). In our study, most frequently HBoV1 $\operatorname{IgM}$ was detected in children aged 13-24 months and the proportion of HBoV1 IgM-positive patients decreased constantly with age $(p=$ $0.005)$. Beyond 24 months merely 5\% had HBoV1 IgM without $\mathrm{IgG}$ antibodies, indicating that HBoV1 acute infection occurs preferentially in children below age two years. These results are consistent with a Finnish-Italian study, where $24 \%$ of patients with community-acquired pneumonia were HBoV1 IgM positive below two years, and $14 \%$ at 2-4 years of age (Don et al., 2009).

In our study, infants with age less of 12 months were positive only for HBoV1 IgG antibodies. A high prevalence of HBoV1 IgG antibodies in infants below six months of age has been shown previously. In these studies, HBoV IgG antibodies were found in over $90 \%$ of infants below three months of age (Endo et al., 2007; Kahn et al., 2008). The high seroprevalence of HBoV1 among young infants is due to maternal antibodies, which have a protective role against HBoV1 infection in the first months of life (SöderlundVenermo et al., 2009; Jartti et al., 2012; Meriluoto et al., 2012).
It has been shown by serology that the seroprevalence increases with age, and at the age of six years almost all children have been infected with HBoV1 and have circulating IgG antibodies (Endo et al., 2007; Kantola et al., 2008; Söderlund-Venermo et al., 2009; Meriluoto et al., 2012; Kantola et al., 2015). In the present study, prevalence rates of virus-specific antibodies also increased along with time from $54 \%$ at $12-24$ months to $85 \%$ at five years of age.

Although, the aetiological role of HBoV1 in respiratory illnesses has been questioned, clinical studies applying more accurate diagnostic markers, such as detection of messenger (m)RNA and viral load assessment in airway samples as well as serology and HBoV1 DNA detection in blood, have provided evidence of $\mathrm{HBoV} 1$ being an important respiratory pathogen in children (Kantola et al., 2008; SöderlundVenermo et al., 2009; Christensen et al., 2010; Don et al., 2010; Deng et al., 2012; Nascimento-Carvalho et al., 2012; Xu et al., 2017; Nascimento-Carvalho et al., 2018). Community-acquired pneumonia, acute wheezing, bronchiolitis, common cold and also otitis media and asthma exacerbations have been reported as clinical manifestations of HBoV1 infection (Jartti et al., 2012; Qui et al., 2017). In our study, among HBoV1 IgM positive patients, pneumonia was diagnosed and confirmed by chest X-ray in 14 patients, whereas acute wheezing in 10 patients. The difference in clinical findings in our patients with serologically verified acute or recent $\mathrm{HBoV} 1$ infection did not reach statistical significance. On the one hand, this can be explained by the fact that all patients in this study did present with LRTI symptoms. On the other hand many viruses do exhibit similar clinical pictures and cannot be clinically differentiated (Pavia, 2011). Although, the exact clinical picture of acute $\mathrm{HBoV} 1$ infection remains to be defined, in several case reports severe and even life-threatening respiratory tract diseases due to HBoV1 in children have been disclosed (Ursic et al., 2011; Körner et al., 2011; Edner et al., 2012; Jula et al., 2013; Ursic et al., 2015; Moesker et al., 2015; Eskola et al., 2017).

The lack of non-symptomatic population controls is a limitation of this study. It would be difficult to collect blood samples from healthy children. However, we believe that the detection of HBoV1-specific IgM and $\operatorname{IgG}$ of patients with LRTI was sufficient to characterise the role of HBoV1 and diagnose acute HBoV1 infection among the study population.

In the literature, the pathogenesis of $\mathrm{HBoV} 1$ has been characterised only provisionally, including HBoV1-specific Tcell immunity. Thus far, the findings suggest that HBoV1 infection can induce production of Th1/Th2 cytokines and therefore play a major role in protection against the disease (Chung et al., 2008; Kumar et al., 2011; Hirose et al., 2014; Guido et al., 2016).

Another limitation of the present study due to economical restrictions was that plasma cytokine levels were measured only in 60 of the 102 patients. It is probable that studying cytokine levels in all patients would have increased the di- 
agnostic yield. In our study, the plasma levels of INF- $\gamma$, IL-4, IL-5 and IL-10 were elevated in patients with evidence of acute HBoV1 infection. In a previous study (Chung et al., 2008) where Th1/Th2 cytokines were analysed in NPAs of children with acute bronchiolitis, the levels of IFN- $\gamma$, IL-2 and IL-4 were higher in HBoV1 DNA-positive patients than in asymptomatic controls. In another study, significantly higher serum levels of TNF- $\alpha$, IL-5 and IL-2 were observed in HBoV1 DNA-positive than in respiratory syncytial virus positive patients (Hirose et al., 2015). However, these studies did not verify acute HBoV1 infections by serology.

\section{CONCLUSIONS}

The results of the present study show that among 102 children hospitalised with LRTI, $18.6 \%$ had an acute or recent HBoV1 infection as proved by the presence of HBoV1specific IgM. In these children also plasma cytokine levels were observed. Furthermore, the seroprevalence of HBoV1specific IgG increased with age, reaching $85 \%$ by five years and LRTI caused by HBoV1 occurred more often in children up to two years of age.

\section{ACKNOWLEDGEMENTS}

We thank Lea Hedman for technical advice in serology. This study was supported in part by the Rīga Stradinš University research project "Epidemiology, pathogenicity of human bocavirus (HBoV) types and their possible connection to lower respiratory tract diseases and acute gastroenteritis in children”, RSU ZP 17/2013, National Research Programme "Biomedicine" project Nr. 5.6.2, the Sigrid Jusélius Foundation, the Life and Health Medical Grant Association, the Jane and Aatos Erkko Foundation, the Medical Society of Finland (FLS), and The Finnish Society of Sciences and Letters.

\section{REFERENCES}

Allander, T., Tammi, M. T., Eriksson, M., Bjerkner, A., Tiveljung-Lindell, A., Anderson, B. (2005). Cloning of a human parvovirus by molecular screening of respiratory tract samples. Proc. Nat. Acad. Sci. USA, 102 (36), 12891-12896.

Allander, T., Jartti, T., Gupta, S., Neisters, H. G. M., Lehtinen, P., Osterback, R., Vuorinen, T., Waris, M., Bjerknen, A., Tiveljung-Lindell, A., van der Hoogen, B. G., Hyypiä, T., Russkanen, O. (2007). Human bocavirus and acute wheezing in children. Clin. Infect. Dis., 44 (7), 904-910.

Anonymous (1995). The management of acute respiratory infections in children: Practical Guidelines for Outpatient Care. World Health Organization, Geneva. 75 pp. (at p. 9).

Bastien, N., Brandt, K., Dust, K., Ward, D., Li, Y. (2006). Human Bocavirus infection, Canada. Emerg. Infect. Dis., 12 (5), 848-850.

Blessing, K., Neske, F., Herre, U., Kreth, H. W., Weissbrich, B. (2009). Prolonged detection of human bocavirus DNA in nasopharyngeal aspirates of children with respiratory tract disease. Pediatr. Infect. Dis. J., 28 (11), 1018-1019.

Christensen, A., Nordbø, S. A., Kroksta, S., Rognlien, A. G., Døllner, H. (2010). Human bocavirus in children: Mono-detection, high viral load and viraemia are associated with respiratory tract infection. Clin. Virol. J., 49 (3), 158-162.

Chung, J. Y., Han, T. H., Kim, J. S., Kim, S. W., Park, C. G., Hwang, E. S. (2008). Th1 and Th2 cytokine levels in nasopharyngeal aspirates from children with human bocavirus bronchiolitis. J. Clin. Virol., 43 (2), 223-225.

Contopoulos-Ioannidis, D. G., Seto, I., Hamm, M. P., Thomson, D., Hartling, L., Ioannidis, J. P., Curtis, S., Constantin, E., Batmanabane, G., Klassen, T., Williams, K. (2012). Empirical evaluation of age groups and age-subgroup analyses in pediatric randomized trials and pediatric meta-analyses. Pediatrics, 129 (3), 161-184.

Deng, Y., Gu, X., Zhao, X., Luo, J., Luo, Z., Wang, L., Fu, Z., Yang, X., Liu, E. (2012). High viral load of human bocavirus correlates with duration of wheezing in children with severe lower respiratory tract infection. PLoS One, 7 (3), e34353.

Don, M., Söderlund-Venermo, M., Valent, F., Lahtinen, A., Hedman, L., Canciani, M., Hedman, K., Korppi, M. (2010). Serologically verified human bocavirus pneumonia in children. Pediatric Pulmon., 45 (2), 120-126.

Edner, N., Castillo-Rodas, P., Falk, L., Hedman, K., Söderlund-Venermo, M., Allander T. (2012). Life-threatening respiratory tract disease with human bocavirus-1 infection in a 4-year-old child. J. Clin. Microbiol., 50 (2), 531-532.

El-Radhi, A.S, Barry, W. (2006). Thermometry in paediatric practice. Arch. Dis. Childhood, 91 (4), 351-356.

Endo, R., Ishiguro, N., Kikuta, H., Teramoto, S., Shirkoohi, R., Ma, X., Ebihara, T., Ishiko, H., Ariga, T. (2007). Seroepidemiology of human bocavirus in Hokkaido prefecture, Japan. J. Clin. Microbiol., 45 (10), 3218-3223.

Eskola, V., Xu, M., Söderlund-Venermo, M. (2017). Severe lower respiratory tract infection caused by human bocavirus 1 in an infant. Pediatric Infect. Dis. J., 36 (11), 1107-1108.

Foulongne, V., Olejnik, Y., Perez, V., Elaerts, S., Rodičre, M., Segondy, M. (2006). Human bocavirus in French children. Emerging Infect. Dis., 12 (8), $1251-1253$.

Fry, A. M., Lu, X., Chittaganpitch, M., Peret, T., Fischer, J., Dowell, S. F., Anderson, L. J., Erdman, D., Olsen, S. J. (2007). Human bocavirus: A novel parvovirus epidemiologically associated with pneumonia requiring hospitalization in Thailand. J. Infect. Dis., 195 (7), 1038-1045.

Guo, L., Wang, Y., Zhou, H., Wu, C., Song, J., Li, J., Paranhos-Baccalą, G., Vernet, G., Wang, J., Hung, T. (2012). Differential seroprevalence of human bocavirus species 1-4 in Beijing, China. PLoS One, 7 (6), e39644.

Guido, M., Tumolo, M. R., Verri, T., Romano, A., Serio, F., De Giorgi, M., De Donno, A., Bagordo, F., Zizza, A. (2016). Human bocavirus: Current knowledge and future challenges. World J. Gastroenterol., 22 (39), 8684-8697.

Hirose, Y., Hamada, H., Wakui, T., Ogawa, T., Terai, M. (2015). Characteristic systemic cytokine responses in children with human bocavirus-positive lower respiratory tract infection. Microbiol. Immunol., 58 (3), 215-218.

Jartti, T., Hedman, K., Jartti, L., Ruuskanen, O., Allander, T., SöderlundVenermo, M. (2012). Human bocavirus - the first five years. Rev. Med. Virol., 22 (1), 46-64.

Jula, A., Waris, M., Kantola, K., Peltola, V., Söderlund-Venermo, M., Hedman, K., Ruuskanen, O. (2013). Primary and secondary human bocavirus 1 infections in a family, Finland. Emerg. Inf. Dis., 19 (8), 1328-1331.

Kahn, J. S., Kesebir, D., Cotmore, S. F., D'Abramo, A., Cosby, C., Weibel, C., Tattersall, P. (2008). Seroepidemiology of human bocavirus defined using recombinant virus-like particles. J. Infect. Dis., 198 (1), 41-50.

Karalar, L., Lindner, J., Schimanski, S., Kertai, M., Segerer, H., Modrow, S. (2010). Prevalence and clinical aspects of human bocavirus infection in children. Clin. Microbiol. Infect., 16 (6), 633-639.

Kantola, K., Hedman, L., Allander, T., Jartti, T., Lehtinen, P., Ruuskanen, O., Hedman, K., Söderlund-Venermo, M. (2008). Serodiagnosis of human bocavirus infection. Clin. Infect. Dis., 46 (4), 540-546. 
Kantola, K., Hedman, L., Arthur, J., Alibeto, A., Delwart, E., Jartti, T., Ruuskanen, O., Hedman, K., Söderlund-Venermo M. (2011). Seroepidemiology of human bocaviruses 1-4. J. Infect. Dis., 204 (9), 1403-1412.

Kantola, K., Hedman, L., Tanner, L., Simell, V., Makinen, M., Partanen, J., Sadeghi, M., Veijola, R., Knip, M., Ilonen, J., Hyoty, H., Toppari, J., Simell, O., Hedman, K., Söderlund-Venermo, M. (2015). B-cell responses of human bocavirus 1-4: New insights from a childhood follow-up. PLoS One, 10 (9), 1-12.

Kesebir, D., Vazquez, M., Weibel, C., Shapiro, E.D., Ferguson, D., Landry, M. L., Kahn, J. S. (2006). Human bocavirus infection in young children in the United States: Molecular epidemiological profile and clinical characteristics of a newly emerging respiratory virus. J. Infect. Dis., 194 (9), 1276-1282.

Körner, R. W., Söderlund-Venermo, M., van Koningsbruggen-Rietschel, S., Kaiser, R., Malecki, M., Schildgen O. (2011). Severe human bocavirus infection, Germany. Emerg. Infect. Dis., 17 (12), 2303-2305.

Kumar, A., Filippone, C., Lahtinen, A., Hedman, L., Söderlund-Venermo, M., Hedman, K., Franssila, R. (2011). Comparison of Th-cell immunity against human bocavirus and parvovirus B19: Proliferation and cytokine responses are similar in magnitude but more closely interrelated with human bocavirus. Scand. J. Immunol., 73 (2), 135-140.

Manning, A., Russell, V., Eastick, K., Leadbetter, G. H., Hallam, N., Templeton, K., Simmonds, P. (2006). Epidemiological profile and clinical associations of human bocavirus and other humanparvoviruses. J. Inf. Dis., 194 (9), 1283-1290.

Martin, E. T., Fairchok, M. P., Kuypers, J., Margaret, A., Zerr, D. M., Wald, A., Englund, J. A. (2010). Frequent and prolonged shedding of bocavirus in young children attending daycare. J. Inf. Dis., 201 (11), 1625-1632.

Martin, E. T., Kuypers, J., McRoberts, J. P., Englund, J. A., Zerr, D. M. (2015). Human bocavirus 1 primary infection and shedding in infants. $J$. Inf. Dis., 212 (4), 516-524.

Meriluoto, M., Hedman, L., Tanner, L., Simell, V., Mäkinen, M., Simell, S., Mykkänen, J., Korpelainen, J., Ruuskanen, O., Ilonen, J., Knip, M., Simell, O., Hedman, K., Söderlund-Venermo, M. (2012). Association of human bocavirus 1 infection with respiratory disease in childhood follow-up study, Finland. Emerg. Infect. Dis., 18 (2), 264-271.

Moesker, F. M., van Kamper, J. J., van der Eijk, A. A., van Rossum, A. M., de Hoog, M., Schutten, M., Smits, S. L., Bodewes, R., Osterhaus, A. D., Fraaij, P. L. (2015). Human bocavirus infection as a cause of severe acute respiratory tract infection in children. Clin. Microbiol. Infect., 21 (10), 964.
Nascimento-Carvalho, C. M., Cardoso, M. R., Meriluoto, M., Kemppainen, K., Kantola, K., Ruuskanen, O., Hedman, K., Söderlund-Venermo, M. (2012). Human bocavirus infection diagnosed serologically among children admitted to hospital with community-acquired pneumonia in a tropical region. J. Med. Virol., 84 (2), 253-258.

Nascimento-Carvalho, A. C., Vilas-Boas, A. L., Fontoura, M. H., Xu, M., Vuorinen, T., Söderlund-Venermo, M., Ruuskanen, O., NascimentoCarvalho, C. M., PNEUMOPAC-Efficacy Study Group. (2018). Serologically diagnosed acute human bocavirus 1 infection in childhood community-acquired pneumonia. Pediatric Pulmonol., 53 (1), 88-94.

Nora-Krūkle, Z., Rasa, S., Vilmane, A., Grāvelsiņa, S., Kālis, M., Ziemele, I., Naciute, M., Petraitiene, S., Mieliauskaite, D., Klimantavicience, M., Girkontaite, I., Liu, H. F., Lin, J. H., Lin, Y. C., Chan, H. C., Gardovska, D. Murovska, M. (2015). Presence of human bocavirus 1 in hospitalized children with acute respiratory tract infections in Latvia and Lithuania. Proc. Latvian Acad. Sci., Section B, 70 (4), 198-204.

Pavia, A. T. (2011). Viral infections of the lower respiratory tract: Old viruses, new Vvruses, and the role of diagnosis. Clin. Infect. Dis., 52 (4), 284-289.

Qui, J, Söderlund-Venermo, M, Young, N. S. (2017). Human Parvoviruses. Clin. Microbiol. Rev., 30 (1), 43-113.

Roth, D. E., Caulfield, L. E., Ezzati, M., Black, R. E. (2008). Acute lower respiratory infections in childhood: Opportunities for reducing the global burden through nutritional interventions. Bull. World Health Org., 86 (5), 356-364.

Söderlund-Venermo, M., Lahtinen, A., Jartti, T., Hedman, L., Kemppainen, K., Lehtinen, P., Allander, T., Ruuskanen, O., Hedman, K. (2009). Clinical assessment and improved diagnosis of bocavirus-induced wheezing in children, Finland. Emerg. Inf. Dis., 15 (9), 1423-1430.

Ursic, T., Steyer, A., Kopriva, S., Kalan, G., Kriver, U., Petrovec, M. (2011) Human bocavirus as the cause of a life-threatening infection. J. Clin. Microbiol., 49 (3), 1179-1181.

Ursic, T., Krivec, U., Kalan, G., Petrovec, M. (2015). Fatal human bocavirus infection in an 18-month-old child with chronic lung disease of prematurity. Pediatric Infect. Dis. J., 34 (1), 111-112.

von Linstow, M. L., Høgh, M., Høgh, B. (2008). Clinical and epidemiologic characteristics of human bocavirus in Danish infants. Pediatric Infect. Dis. J., 27 (10), 897-902.

Xu, M., Arku, B., Jartti, T., Koskinen, J., Peltola, V., Hedman, K., Söderlund-Venermo, M. (2017). Comparative diagnosis of human bocavirus 1 respiratory infection with messenger RNA reverse-transcription polymerase chain reaction (PRC), DNA quantitative PCR, and serology. J. Infect. Dis., 215 (10), 1551-1557.

\section{SEROLOĢISKI NOTEIKTAS CILVĒKA BOKAVĪRUSA 1 INFEKCIJAS BIEŽUMS HOSPITALIZĒTIEM BĒRNIEM AR DZIL,ĀKO ELPCEL̨U INFEKCIJU LATVIJĀ}

Kopš cilvēka bokavīrusa (HBoV) 1 atklāšanas 2005. gadā tas tiek uzskatīts par vienu no vizplatītākajiem elpceḷu vīrusiem pasaulē. Pierādīts, ka HBoV1 ierosina akūtas augšējo un dziḷāko elpceḷu infekcijas bērniem. Infekcijas noteikšanai bieži tiek pielietota polimerāzes kēes reakcija (PKRR), taču, ṇemot vērā, ka HBoV1 klātbūtne augšējo elpceḷu sekrētā var būt ilgstoša un tā bieži tiek noteikta kopā ar citiem elpceḷu vīrusiem, pozitīvu kvalitatīvās PĶR rezultātu interpretācija ir sarežg̀îta. Šì pētījuma mērkis bija noskaidrot akūtu HBoV1 infekciju biežumu, nosakot HBoV1 specifisko IgM un IgG klases antivielu klātbūtni, pētīt pirmā un otrā tịpa T līdzētājšūnu citokīnu koncentrāciju plazmas paraugos un aprakstît akūtas HBoV1 infekcijas klīniskās īpatnības hospitalizētiem bērniem ar akūtu dziḷāko elpceḷu infekciju vecumā līdz pieciem gadiem. HBoV1 specifiskās IgM klases antivielas tika konstatētas 19/102 (18,6\%) un IgG klases antivielas 66/102 $(64,7 \%)$ pacientiem. Visbiežāk HBoV1 IgM klases antivielas tika konstatētas pacientiem vecumā no 13 līdz 24 mēnešiem. Pneimonija un akūta sēkšana bija visbiežāk noteiktās diagnozes pacientiem ar akūtu HBoV1 infekciju. HBoV1 IgG seroprevalence pieauga līdz ar pacientu vecumu, sasniedzot $85 \%$ līdz piecu gadu vecumam. Citokīnu INF-gamma, IL-4, IL-5 un IL-10 augstākas koncentrācijas tika noteiktas pacientiem ar akūtu HBoV1 infekciju. 